\section{1. まえがき}

回分蒸溜は非定常状態下の蒸溜であるから，分離条件 を満足する段数と遗流比の計算は，連続蒸溜のことく簡 单でなく，一般に塔ホールドフップを無視し，有限一定 選流比下で溜出を行了場合に限定，ラウール法則を仮定 し得てる，以わ的る蒸溜曲線式で試行法に上って計算し なければならない。したがって，速続蒸溜における平田 氏5)，Gilliland") の相関関係のことく，分離条件を知っ てただらに段数と透流比をあた古る計算式の確立は，回 分蒸溜工学上の一課通であった。

回分蒸溜の段数と還流比の簡易計算式をめさした既往 研究には，標準分離に対与る Rose8 の式があり，また ボールハイトを用いた Bowman \& Cichelli など1,2); Zuiderweg ${ }^{10)}$ ，Houtman \& Husain施などによる計算 式がある。しかし，標準分離性回分蒸溜の一分離条件に すぎずまたボールハイトによる計算式は，一応のまと まりをむつか，その利用にあたって分離条件としてのポ ールハイトの决定に笂問がのこされている。

本報は，つぎの条件下一正なわち，1）混合物は2 成分系である，2）有限一定僄流比下て溜出を行了，3） 塔内ホールドアッブは無視する，4）比揮発度は一定で ある一の回分蒸留に対してまず，同一ボールハイト下 の段数と票流比の相関関俰得た。つきに分離条件とし て，平均溜出組成と軽質成分の回収率を選択し，最小理 論段数と最小谴流比の計算式を導入，また各種の比揮発 度について各種の平均溜出組成と軽質成分の回収率を満 足する段数と逞流比を計算，これらにるとついて平均溜 出組成々軽質成分回収率を分離策件とした，段数と還流 比の相関関係をしめしたるのである。

\section{2. 同一ボールハイト下の段数と} 逼流比の相関関係

1. ポールハイトの計算 有限一定還流比下の回分 蒸留結果は，一般につぎ蒸溜曲線式によって代表され

$$
\int_{1}^{W} \frac{d W}{W}=\int_{x_{0}}^{x_{W}} \frac{d x_{W}}{x_{D}-x_{W}}
$$

分離の良否は，特定の溜出点に括ける平均溜出組成，2

- 昭和 33 年 12 月 12 日受理

* 日本大学工学部 *** 日本原子力研究所

$\dagger と<K x_{D}$ 対 $W$ の图表上の倠でるる。
つの瞬間溜出組成間の溜分量の大小などよって判定さ れていた。しかるに Bowman ら゙'は瞬間溜出組成が 50 モル\%軽質成分であるときの蒸溜曲線の傾斜† 々残液量 対仕込量の稍をポールハイトと定義し，ポールハイトに よる蒸溜結果の判定法を提案した。ポールハイトは仕迟 組成のみが異なる蒸溜曲線に対して同一值が得られるの で, 操作变数としての仕込組成を考虑することなく問題 を論ずることができ，また脌析的に計算しらる利点をむ つなど，理論的に有用な分離条件である。

定義によってポールハイトは，次式であたえられる。

$$
S=\left[W\left(\frac{d x_{D}}{d W}\right)\right]_{x_{D}=0.5}
$$

ここで（1）式の微分形， $d W / W=d x_{W} /\left(x_{D}-x_{W}\right)$ を(2) 式に代入すると，ボールハイトは次式であらわされる。

$$
S=\frac{0.5-\left(x_{W}\right)_{S}}{\left(d x_{W} / d x_{D}\right)_{S}}
$$

したがって，有限還流比と有限段数下のポールハイト は，以下にしたがって（3）式から計算しらる2。すなか ち，つきの Smoker 式”を用いて

$$
x_{W}=x_{K}+\frac{m^{n} C^{2 n}\left(x_{D}-x_{K}\right)}{\alpha^{n}-m C(\alpha-1)\left(\frac{\alpha^{n}-m^{n} C^{2 n}}{\alpha-m C^{2}}\right)\left(x_{D}-x_{K}\right)}
$$

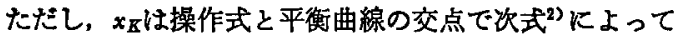
あたえられる。

$$
\begin{array}{ll}
x_{K}=\frac{-B^{\prime}-\sqrt{B^{\prime 2}-4 A^{\prime} C^{\prime}}}{2 A^{\prime}} \\
A^{\prime}=m(\alpha-1) \\
B^{\prime}=m+b(\alpha-1)-a \\
C^{\prime}=b=x_{D} /(R+1)
\end{array}
$$

である。まず（4)，(5) 式を $x_{D}$ で微分して，それぞれ 次式を5る

$$
\begin{aligned}
& \left(d x_{W} / d x_{D}\right)_{s}=h[1-e f h(1-g)] \\
& +\{1-h[1-2 e(n-f)-e f h(1+g-e\{1 \\
& -g+2 n\})]\}\left(\frac{d x_{K}}{d x_{D}}\right)_{s} \\
\beth こ K & \\
e & \left.=\left(x_{D}-x_{K}\right)(\alpha-1) / C, f=m C^{2} /\left(\alpha-m c^{2}\right)\right\} \\
g & =\alpha^{n} / m^{n} C^{2 n} \\
h & =\left(x_{W}-x_{K}\right) /\left(x_{D}-x_{K}\right) \equiv 1 /\{g+e f(1-g)\}
\end{aligned}
$$




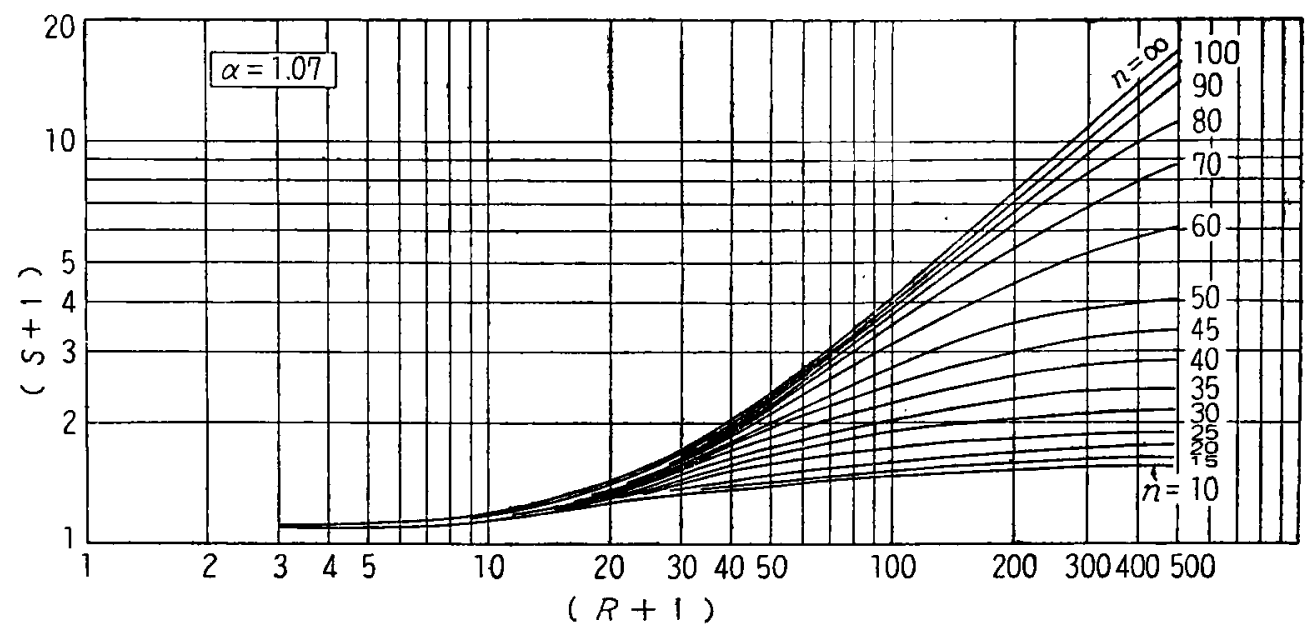

Fig. 1 Effect of reflux ratio on pole height for various number of theoretical plates

$$
\left(\frac{d x_{K}}{d x_{D}}\right)_{s}=\left(\frac{b}{m}\right)\left(\frac{2 m-B^{\prime}}{\sqrt{B^{\prime 2}-4 A^{\prime} C^{\prime}}}-1\right)
$$

また，别に（8）式より次式を弓る。

$$
\left(x_{W}\right)_{S}=\left(x_{K}\right)_{S}+(h)_{S}\left\{0.5-\left(x_{K}\right)_{S}\right\}
$$

かくして, (6) （10）式の各值の計算によって，ポルハイド得られる。

つぎに，全還流と段数無限大下のポールハイトは，そ れ先れ次式によってあたえられる。

$$
\begin{gathered}
S=\frac{\alpha^{2 n \prime}-1}{8 \alpha^{n \prime}} \\
S=\left\{0.5-\left(x_{K}\right)_{S}\right\} /\left(\frac{d x_{K}}{d x_{D}}\right)_{S}
\end{gathered}
$$

ポールハイトの計算順序としては， $\alpha ， R$ を適当に定 め、また $n$ を定めて，まず $R /(R+1)$ 加 $m$ を求め， $b$ (または $\left.C^{\prime}\right) ， A^{\prime} ， B^{\prime}$ の值を $x_{D}=0.5$ に扔いて計算し， $x_{K}$ を（5）式から，また $C$ と $\left(x_{D}-x_{K}\right)$ をそれぞれ求め る。つきに， $, f, g$ を(7) 式加ら， $h$ を(8) 式から

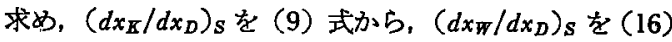
式から，また $\left(x_{W}\right)_{S} を(10)$ 式で計算し，最後に（3） 式からポールハイトが得られる。

Fig. 1 および Fig. 2 は, $\alpha=1.07$ および 1.25 につ いて計算したポールハイトの值を， $n$ の一定値について $(S+1)$ と $(R+1)$ の関係として両対数図表に整理した るのである。

2. 同一ポールハイト下の相関関係 Fig. 3 は, Fig. 1 扎よび Fig. 2 の計算結果と別に（11）式より求 めた最小理論段数とポールハイトの計算値にもとずき, 同一ポールハイトに抽る， $n, n^{\prime}, R, R^{\prime}$ の相関関係を

* 文献 2) の Table 1 中, $\left(R-R^{\prime}\right) /(R+1)>0.75$ となる 3つを のぞいたすべての值をかくむ。なお $\left(R-R^{\prime}\right) /(R+1)>0.75$ は分離が医 あて容易な场合である。
求めた綕合結果である。

ここに, Fig. 3 は $\alpha=1.07$ 特よび 1.25, $S=1 \sim 20$ の 段数と罢流比にもとずいて作成した相関関係であるが， $a=1.05 \sim 5.00, S=1.8 \sim 77.6$ の範围で不規則に求めら れた Bowman ら の計算值*すよく相関関係を满足す るから、ひろく蒸溜条件を考虑した一般的な相関関係と みなしらるものである。また Fig. 3 より，0.15く(Rー $\left.R^{\prime}\right) /(R+1)<0.50$ の範囲内では相関関倸は次式によ。 てあらわされる。

$$
\begin{gathered}
\log \alpha^{0.281} \cdot\left(\alpha^{n \prime}-\frac{1}{\alpha^{n \prime}}\right)^{0.149} \cdot\left(\frac{n-n^{\prime}}{n+1}\right) \\
=-\left(\frac{R-R^{\prime}}{R+1}\right)-0.056
\end{gathered}
$$

Fig. 3 あるいは（13）式の利用にあたって，最小理論段 数と最小還流比は，つきの近似式 ${ }^{2 》}$ で計算することがで きる。

$$
\left.\begin{array}{l}
n^{\prime} \doteqdot \log 8 S / \log \alpha, \quad(n>1, \quad S>1) \\
R^{\prime} \doteqdot 2 S /(\alpha-1), \quad(1<R<3, \quad S>1 / 2) \\
R^{\prime} \doteqdot 2(S+1 / 4) /(\alpha-1), \quad(R>3, S>1 / 2)
\end{array}\right\}
$$

なお, Fig. 3 あるいは (13) 式中の $\alpha^{0.281},\left(\alpha^{n \prime}-1 /\right.$ $\left.\alpha^{n \prime}\right)^{0.149}$ 項は, 同一ポールハイト下の $\log \left(n-n^{\prime}\right) /(n+$ 1) 対 $\left(R-R^{\prime}\right) /(R+1)$ の関係か， $\alpha$ 特よび $S$ にって 異なるので, これに対する補正項であり，sについては （11）式を代入して $\alpha^{n \prime}$ の函数として整理したものであ る。 また $n>1, S>1$ の場合には $\left(\boldsymbol{a}^{n \prime}-1 / \boldsymbol{a}^{n \prime}\right)$ は $\boldsymbol{\alpha}^{n \prime}$ とおいてさしつかえない。

\section{3. 平均溜出組成上軽筫成分回收率を分部条件 とした場合の最小理論段数と最小遥流比の計算式}

同一ポールハイト下の段数と摆流比の相関関俰を得た 
が、この利用にあたってをず分離策 件としてのポールハイトを決定しな ければならない。したがって Bowman ら22 は分離条件としてのポー ルハイトの決定法をも論している。

しかしかような手数をはぶき，かつ より明確で定量的な分蜼条件に対し て，段数之罡流比の相関関倸がえら れれば好都合である。

このよ5な観点から，定量的でし かる仕込組成を考虑した分離条件と して, 平均溜出組成 $x_{D}$ av と仕込中 の軽質成分の回収率 $\eta$ を選択するこ とは望ましいことであろう。例えば 平均溜出組成を，95 モ几\%軽質成分 とし什込中の軽質成分の $90 \%$ を回収 するには段数と還流比いかんという 命題について計算式を求むるにあ

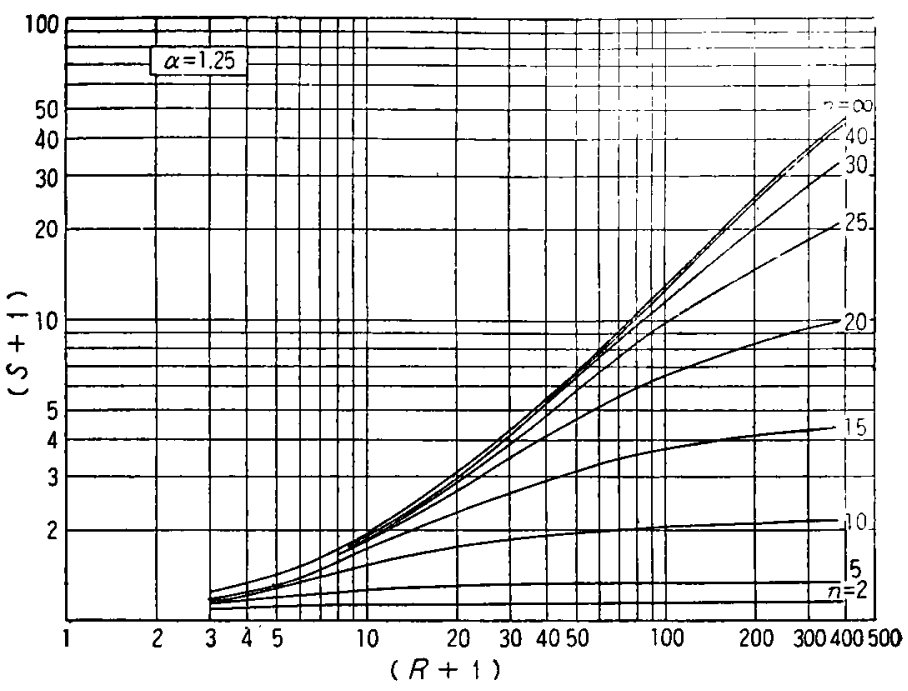

Fig. 2 Effect of reflux ratio on pole height for various number of theoretical plates

る。かくしてポールハイト同様な相 関関係をめさすとき，ます最小理論段数と最小還流 比の計算式を解明しなければならない。

1. 最小理論段数の計算式 分離条件としての $x_{D}$ av， $\eta$ を満足する最小理論段数の計算式は，つき のことく導入しうる。すなわち，全還流下の䁘間溜 出組成と瞬間釜液組成の関保はつぎの Fenske 式 ${ }^{3)}$

$$
\frac{x_{D}}{1-x_{D}}=\alpha^{n}\left(\frac{x_{W}}{1-x_{W}}\right)
$$

であらわされるので (15) 式を(1) 式代入積分し て,つぎ蒸梅曲線式をうる。

$$
\log W=\left(\frac{1}{\alpha^{n \prime}-1}\right)\left\{\log \frac{x_{W}}{x_{0}}+\alpha^{n \prime} \log \frac{1-x_{0}}{1-x_{W}}\right\}
$$

またべつに蒸溜塔をめぐる物質収支より次式をう る。

$$
\begin{aligned}
& \beta=1-W \\
& \beta x_{D} \text { a }=x_{0}-W x_{W}
\end{aligned}
$$

ここで，平均溜出組成扣よび次式であたえられる軽 質成分の回収率

$$
\eta \equiv \beta x_{D} \text { av } / x_{0}
$$

を（17），(18）式に代入して最後の鉒夜量と鉒夜組成を 求めると,

$$
\begin{gathered}
W=1-\eta x_{0} / x_{D \text { av }} \\
x_{W}=x_{0}(1-\eta) /\left(1-\eta x_{0} / x_{D \text { av }}\right)
\end{gathered}
$$

をうる。

したがって (20)，(21）式であたえられる $W ， x_{W} を$ （16）式に代入整理し，かつ $n^{\prime}$ にいて解くと最小理論

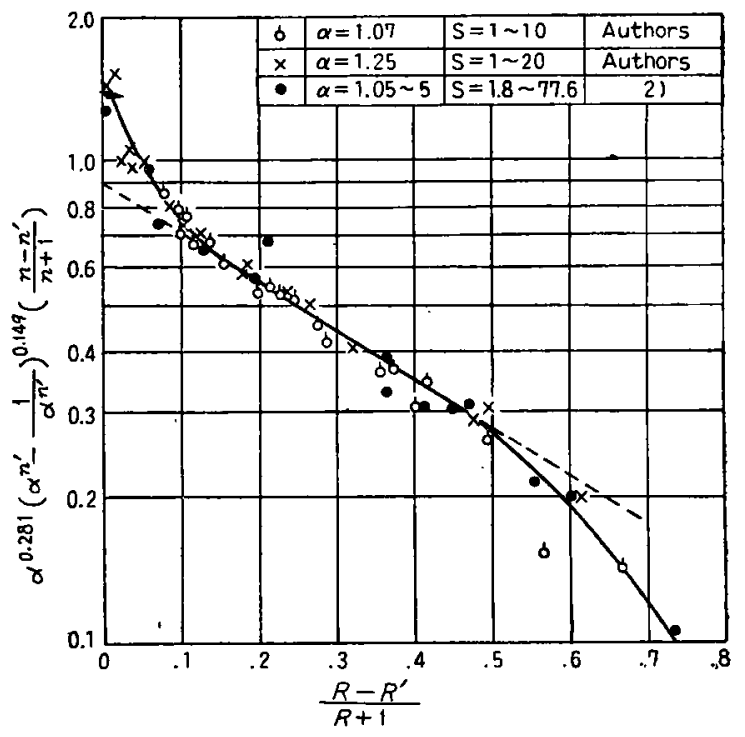

Fig. 3 Correlation between number of theoretical plates and reflux ratio based on the same values of pole height

段数の計算式として次式をらる。

$$
n^{\prime}=\frac{1}{\log \alpha} \log \left(\frac{\log (1-\eta)}{\log (1-\delta)}\right)
$$

ここに $\delta=\eta\left[x_{0} /\left(1-x_{0}\right)\right]\left[\left(1-x_{D \mathrm{av}}\right) / x_{D \mathrm{av}}\right]$ である。

2. 最小遺流比の計算式 分離条件としての $x_{D}$ av $\eta$ を満足する最小還流比は，ます段数無限大下の瞬間溜 出組成と瞬間鉒液組成の関係か，操作線と平衡曲線の交 点として,つきのこととくたえられるので， 
Table I Number of theoretical plates calculated by Equation $26^{\text {a) }}$

\begin{tabular}{|c|c|c|c|c|c|}
\hline $\begin{array}{l}\text { relative } \\
\text { volatility }\end{array}$ & $\begin{array}{l}\text { average com- } \\
\text { position of } \\
\text { distillate }\end{array}$ & $\begin{array}{l}\text { yield of more } \\
\text { volatile com- } \\
\text { ponent }\end{array}$ & $\begin{array}{l}\text { reflux } \\
\text { ratio }\end{array}$ & theoretical & plate \\
\hline$\alpha$ & $x_{D \text { av }}$ & $\eta$ & $R$ & $n^{(\mathrm{b})}$ & $n_{\text {corr }}{ }^{c)}$ \\
\hline $\begin{array}{l}1.05 \\
1.05 \\
1.05 \\
1.05 \\
1.07 \\
1.07\end{array}$ & $\begin{array}{l}0.90 \\
0.90 \\
0.90 \\
0.95 \\
0.90 \\
0.90\end{array}$ & $\begin{array}{l}0.90 \\
0.90 \\
0.90 \\
0.90 \\
0.90 \\
0.90\end{array}$ & $\begin{array}{r}80 \\
100 \\
120 \\
120 \\
60 \\
70\end{array}$ & $\begin{array}{r}151.5 \\
101.5 \\
88.7 \\
140.7 \\
93.0 \\
74.0\end{array}$ & $\begin{array}{r}148.0 \\
105.0 \\
92.0 \\
124.0 \\
93.1 \\
75.7\end{array}$ \\
\hline $\begin{array}{l}1.07 \\
1.07 \\
1.25 \\
1.25 \\
1.25 \\
1.25\end{array}$ & $\begin{array}{l}0.90 \\
0.85 \\
0.90 \\
0.90 \\
0.90 \\
0.95\end{array}$ & $\begin{array}{l}0.90 \\
0.85 \\
0.90 \\
0.90 \\
0.90 \\
0.90\end{array}$ & $\begin{array}{l}90 \\
47 \\
16 \\
20 \\
24 \\
23\end{array}$ & $\begin{array}{l}63.5 \\
67.0 \\
31.5 \\
22.0 \\
19.4 \\
27.0\end{array}$ & $\begin{array}{l}63.8 \\
87.2 \\
26.6 \\
20.4 \\
18.2 \\
26.7\end{array}$ \\
\hline $\begin{array}{l}1.50 \\
1.50 \\
1.50 \\
1.50 \\
2.00 \\
2.00\end{array}$ & $\begin{array}{l}0.90 \\
0.90 \\
0.90 \\
0.85 \\
0.90 \\
0.90\end{array}$ & $\begin{array}{l}0.90 \\
0.90 \\
0.90 \\
0.85 \\
0.90 \\
0.90\end{array}$ & $\begin{array}{r}9 \\
11 \\
13 \\
10 \\
5 \\
6\end{array}$ & $\begin{array}{r}13.2 \\
11.1 \\
10.3 \\
8.5 \\
7.1 \\
6.2\end{array}$ & $\begin{array}{r}12.7 \\
11.0 \\
10.2 \\
8.7 \\
6.6 \\
6.1\end{array}$ \\
\hline $\begin{array}{l}2.00 \\
2.00 \\
2.50 \\
2.50 \\
2.50\end{array}$ & $\begin{array}{l}0.90 \\
0.85 \\
0.95 \\
0.95 \\
0.95\end{array}$ & $\begin{array}{l}0.90 \\
0.85 \\
0.76 \\
0.76 \\
0.76\end{array}$ & $\begin{array}{l}8 \\
5 \\
\mathbf{3} \\
\mathbf{5} \\
\mathbf{7}\end{array}$ & $\begin{array}{l}5.5 \\
5.0 \\
5.8 \\
4.8 \\
4.4\end{array}$ & $\begin{array}{l}5.6 \\
5.1 \\
6.0 \\
5.0 \\
4.5\end{array}$ \\
\hline
\end{tabular}

a) based on equimolar mixture

b) calculated by Equation 26

c) calculated by Equation 27 \& Fig. 5
び（21）式であたえられるのて，これを

(1) 式に代入すると次式を 5 る。

$$
\begin{aligned}
& 2.3 \log \left(1-\eta x_{0} / x_{D \mathrm{av}}\right) \\
& =\int_{x_{0}}^{x_{0}(1-\eta) /\left(1-\eta x_{0} / x_{D \mathrm{DV}}\right)} \frac{d x_{W}}{x_{D}-x_{W}}
\end{aligned}
$$

したがって， $x_{D \text { av }} \eta$ を満足する段数と 還流比の值は，まず一の還流比を定め これに対して種々なる段数を仮定する。 しかるのち，それぞれの段数について瞬 間溜出組成と瞬間金液組成の一連の関係 值を計算，(26）式に代入してあたえら れた積分限界まて図積分を行う。しかる とき積分值が左辺の值と一致することき 段数を試行法で求めれば，還流比に対し て $x_{D \text { av }}, \eta$ を满足する段数をうる。

Table 1 は, $\alpha=1.05 \sim 2.50, x_{0}=0.50$ とし，かつ実際の蒸溜で要求される比較 的分離がよい条件について， $x_{D \mathrm{aV}} ， \eta$ を 任意にえらび，分離条件を満足する段数 と還流比を（26）式から計算した結果で ある。この計算にあたって, 瞬間溜出組 成と瞬間金夜組成の関係值は Smoker 式

$$
x_{D}=\frac{\left(R^{\prime}+1\right) a x_{W}}{1+(\alpha-1) x_{W}}-R^{\prime} x_{W}
$$

（23）式を（1）式に代入して，つきの蒸溜曲線式をう 万。

$$
\begin{aligned}
\log W= & \left(\frac{1}{R^{\prime}+1}\right)\left(\frac{1}{\alpha-1}\right) \\
& \left\{\log \frac{x_{W}}{x_{0}}+\alpha \log \frac{1-x_{0}}{1-x_{W}}\right\}
\end{aligned}
$$

つぎに，最小理論段数の場合とまったく同様にして， (20)，(21）式であたえられるW，利を（24）式に代 入整理し， $R^{\prime}$ Kついて解き，最小還流比の計算式として 次式を弓る。

$$
R^{\prime}=\frac{\log (1-\eta)-\alpha \log (1-\delta)}{(\alpha-1) \log (1-\beta)}
$$

ここに $\beta$ は溜出密で (19) 式より， $\beta=\eta x_{0} / x_{D}$ av であた えられる。

（22）（25）を用万れば， $\alpha ， x_{0} ， x_{D}$ av， $\eta$ を既知とし て，この分離に必要な最小理論段数と最小還流比を容易 と計算することができる。

\section{4. 平均溜出組成と軽兵成分回収率を分離条件 とした場合の段数と還流比の相関関保}

1. 段数と逼流比の計算平均溜出組成と軽質成分 回収率を既知とするとき，W，称はそれぞれ（20）およ
で求め，図積分は梯形法則によった。 軽質成分回収率にるとずく段数と還流比の相関関係を求 めるにあたっては，分離条件 $x_{D \mathrm{av}}, \eta$ を同時に考庶しな ければならず，またこの分離条件を满足する段数と還流 比の計算が困難であるから，さきに得た同一ポールハイ ト下の相関関係のことく簡単に求め得ない。したがって $x_{D \mathrm{av}}, \eta$ を分離条件とした相関関係を求めるについて,

Fig. 4 は， $x_{D \mathrm{aV}} ， \eta$ を一定とした場合の段数と還流 比と同一ポールハイト下の段数と還流比の一般関係を説 明するあのであり，図ではとくに Table 1 の $a=1.50$, $x_{0}=0.5, x_{D \mathrm{av}}=0.9, \eta=0.9$ の $n$ と $R$ を(22) 扰よび (25) 式から求めた $n^{\prime} ， R^{\prime}$ をくめてえがいてある。ま た点楾で示したすのは， $x_{D \text { av }}=0.9 、 \eta=0.9$ の段数と還 流比の值に対して，ポールハイトの最大值と最小值を計 算し， 2 つのポールハイトに対して，Fig. 3 から段数と 遗流比の関係を求めたるのである。Fig. 4 から，分離策 件 $x_{D}$ av， $\eta$ を一定とした場合には，段数と這流比の值に よってポールハイトの值は異なり一定值を示さない。し かし、ポールハイトの变化範囲は限定されており， $x_{\boldsymbol{D} \text { av }}$ $\eta$ を一定とした場合の $n^{\prime}$ および $R^{\prime}$ にもとつき，(14） 式で計算したボールハイト*(次百) で最大值と最小值が規

\section{2. 段数と瀷流比の相関関係 さて平均溜出組成と} 同一ポールハイト下の相関関係の利用を考察した。 


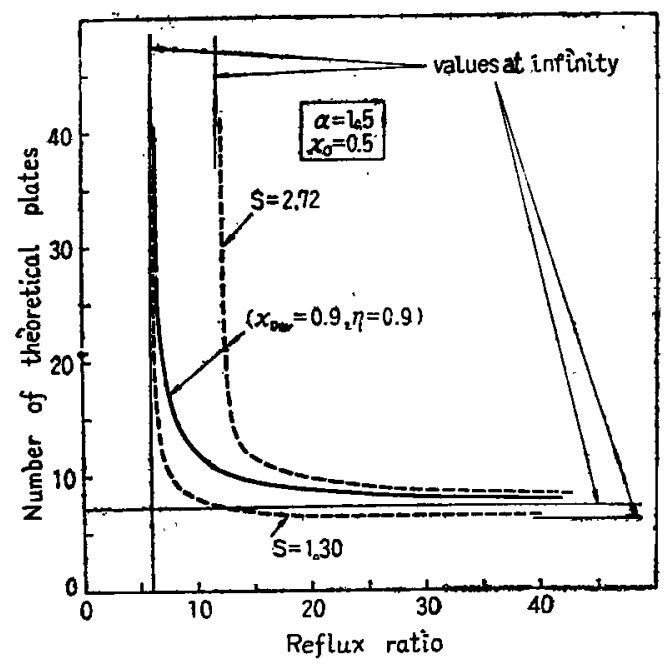

Fig. 4 Relation between $x_{\mathrm{Da}}$ \& q-carve and $S$-constant curve

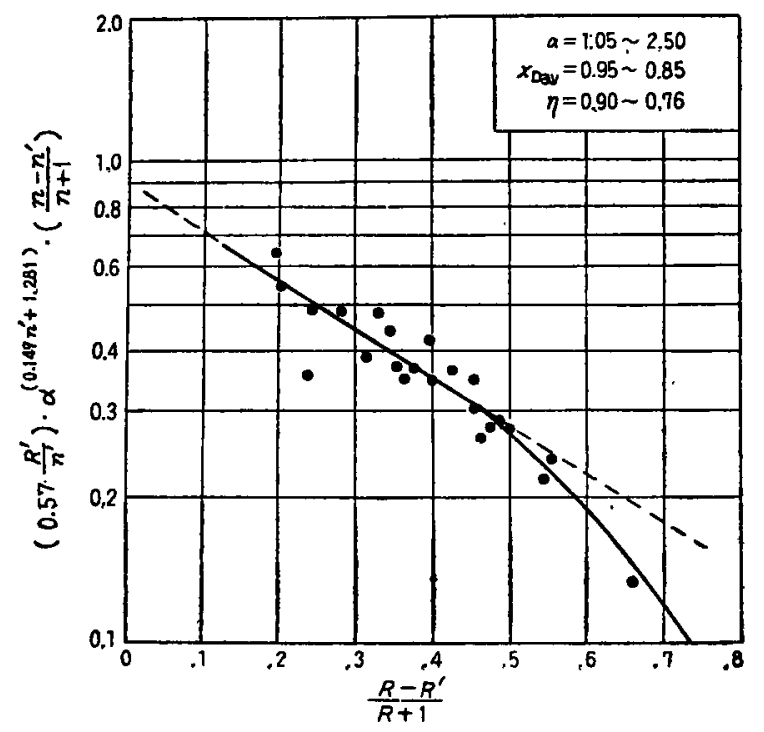

Fig. 5 Correlation between number of theoretical pla. tes and reflux ratio based on the average composition of distillate and yield of more volatile component

定される。

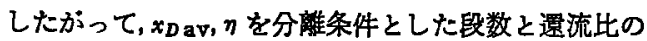
相関関係を求めるについて，ます $x_{D}$ av， $\eta$ を满足する $n^{\prime}, R^{\prime}$ を計算し，つきにまったく便宜的に同一ポールハ イト下の相関関係を利用し， $x_{D}$ av， $\eta$ を満足する $n^{\prime}, R^{\prime}$ にもとづき段数と避流比の值を算出, かつ Table 1 の 值と比較し，両者が一致する条件を求めると，ポールハ イトの相関閣係を $\propto 0.57 R^{\prime} / n^{\prime}$ の積で補正すれぱよい

欮更 * $S \div \alpha^{n \prime} / 8, S=R^{\prime}(\alpha-1) / 2$ 又は $S=R^{\prime}(a-1) / 2-1 / 4$
ことを見出した。

Fig. 5 は（26）式で計算した Table 1 のと $R$, ヤ つ（22），(25）式から求めた $n^{\prime} ， R^{\prime}$ の值にもとつ!， て作成した，求める平均溜出組成と軽質成分回収率を分 離条件とした段数と，還流比の相関関係である。ここに Fig. 5 から, $0.15<\left(R-R^{\prime}\right) /(R+1)<0.50$ の範用内て は相関関係は次式であらわしうる。

$$
\begin{aligned}
& \log \left(0.57 \frac{R^{\prime}}{n^{\prime}}\right) \cdot \alpha^{\left(0.149 n^{\prime}+1.281\right)} \cdot\left(\frac{n-n^{\prime}}{n+1}\right) \\
& =-\left(\frac{R-R^{\prime}}{R+1}\right)-0.056
\end{aligned}
$$

Table 1 中, 計算值とあるは，相関関俰 (27) 式拉よび Fig. 5 を利用して求めた值であり，（26）式からの值を 良好な一致を示している。

平均溜出組成と軽質成分回收率の相関関係にしたがっ

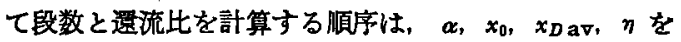
既知として，まず分離条件 $x_{D \mathrm{av}}$ 》をを满足する $n^{\prime}, R^{\prime}$ を (22) および (25) 式からそれぞれ求め， $\boldsymbol{a}^{\left(0.149 n^{\prime}\right.}$ +1.281) および $0.57 R^{\prime} / n^{\prime}$ を計算する。つぞに選 流比 $R$ を定めて $\left(R-R^{\prime}\right) /(R+1)$ をえ, Fig. 5 または (27) 式の相関関保より， $\left(0.57 R^{\prime} / n^{\prime}\right)$ ・ $a^{\left(0.149 n^{\prime}+1.281\right)} \cdot\left[\left(n-n^{\prime}\right) /(n+1)\right]$ を知れば, $[(n$ $\left.\left.-n^{\prime}\right) /(n+1)\right]$ がえられ，段数 $n$ を決定し 5 る。

Fig. 5 あるいは（27）式でまとめられた相関関 係は，比較的良好な分離を対称としてえたものて あり，この点䓧端に鋭い、分離あるいは極端に低い 分離への適用を除外すれば，一般性をるつるのと 見做しらるたろら。また，本相関関係はホールド フップ無視の仮定下に得られたるのであるから， 仕边量に比べて塔内ホールドフップが無視しうる 場合には，正確に適用し 5 る。かし，ホールド アッブを考虑する場合です，さきの研究てで得た 蒸溜曲線に扣よほチすールドアップの影帮から判 断して，低還流比にお゙いてはホールドフップの存 在は分離を改良し，一方高還流比に招いてホール ドアッブの存在が分離を改覀するといっても, 改 悪の割合は僅小であり，ホールドアップ無視の场 合に比較してホールドアップを考虑した場合が棩 常に多くの段数を要するとは考えられない。したがって， ホールドアップ無視の仮定下に得られた段数は，還流比 が比較的小さい場合には十分余裕ある段数をあたえるる のとし，一方高還流比においては，その段数が近似的に 満足な值であるとして，ホールドフッブを考虑した場合 にも適用しうるであろう。

\section{5. むす ひ}

一定還流比下て溜出を行 5，2成分系の回分蒸溜につ 
ついて，塔内ホールドフップ無視，一定比揮発度を仮定 しつきの諸項を得た。

1) 分離条件としてポールハイトを用い，同一ポール ハイトに対する段数と還流比の相関関係を得た。

2）分離条件として平均留出組成と仕込中の軽質成分 の回収率を用い，最小理論段数と最小還流比の計算式を 得た。

3）分離条件として平均溜出組成と仕込中の柽質成分 の回収率を用い，段数と還流比の相関関係を得た。

平均溜出組成と軽質成分回取率にもとすく，段数と遠 流比の相関関係は，連続蒸溜に括ける相関関係と同㥞， 回分蒸溜塔の設計沉役立つものと思う。

付記 : 御鞭達をいただいた都立大学平田光穂博士に厚 く感㛛の意を表する。

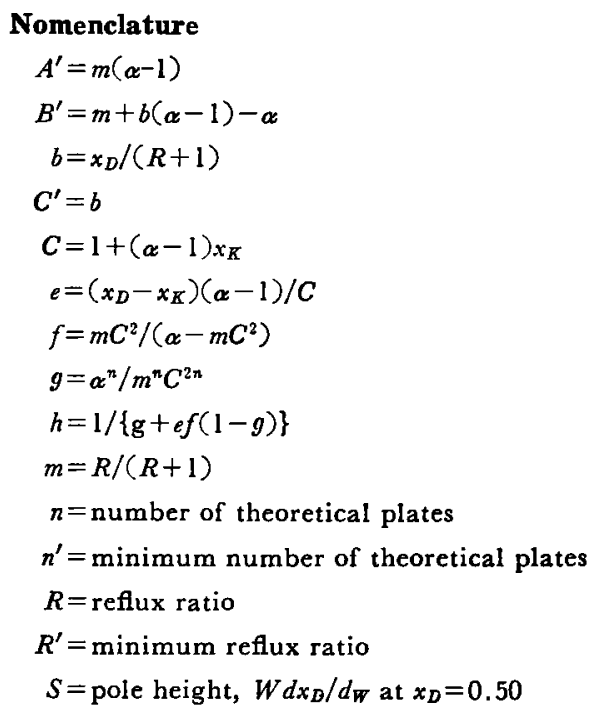

$W=$ amount of mixture in still, expressed as a mole fraction of the original charge $x=$ mole fraction of the more volatile component in the liquid phase

$x_{D}$ : instantaneous distillate composition

$x_{D}$ av : average composition of distillate $x_{K}: x$ coordinate of the intersection of the equilibrium and operating line, $\left\{-B^{\prime}-\sqrt{B^{\prime 2}-4 A^{\prime} C^{\prime}}\right\} / 2 A^{\prime}$

$x_{0} \div$ original charge composition

$\boldsymbol{x}_{W}:$ instantaneous still composition $\boldsymbol{a}=$ relative volatility

$\boldsymbol{\beta}=$ amount of distillate, expressed as a mole fraction of the original charge, $\eta x_{0} / x_{D}$ av

$\delta=\eta\left\{x_{0}\left(1-x_{D \mathrm{av}}\right) /\left(1-x_{0}\right) x_{D \mathrm{av}}\right\}$

$\eta=y i e l d$ of the more volatile component, $\beta x_{D}$ av $/ x_{0}$

Subscript

$S:$ refers to the condition, $x_{D}=0.5$

\section{Literature cited}

1) Bowman, J. R. 41, 1985 (1949)

2) Cichelli, M. T., Weatherford, W. D., Bowman, J. R. \& Coull, J. : ibid., 42, 2502 (1950)

3) Fenske, M. R. . ibid., 24, 482 (1932)

4) Gilliland, E. R. : ibid., 32, $1220(1940)$

5) Hirata, M. . Chem. Eng. (Japan), 19, 44 (1955)

6) Houtman, J. P. W. \& Husain, A. : Chem. Eng. Scien. $c e, 5,178$ (1956)

7) Kojima, K.: Chem. Eng. (Japan), 22, 492 (1958)

8) Rose, A. : Ind. Eng. Chem., 33, 594 (1941)

9) Smoker, E. H. : Trans. Am. Inst. Chem. Engrs., 34, 165 (1938)

10) Zuiderweg, F. J. . Chem. Eng. Tech., 25, 297 (1953)

\title{
Correlation between the Number of Theoretical Plates and Reflux Ratio in the Binary Batch Distillation
}

\author{
Kazuo Kojima* and Isao Aoyama**
}

Studies were conducted on the binary batch distillation at constant reflux ratio, on the assumption (for the sake of simplicity) that the holdup was negligible and molal down flow and relative volatility were constant. The results obtained may be summarized as follows :

1) Based on the same value of pole height for the sharpness of separation, the correlation between the number of theoretical plates and reflux ratio was obtained as shown in Fig. 3, where the values of $\left(R-R^{\prime}\right) /(R+1)$ ranged from 0.15 to 0.50 , said correlation being represented by the following equation. 


$$
\log \alpha^{0.281} \cdot\left(\alpha^{n \prime}-\frac{1}{\alpha^{n \prime}}\right)^{0.149} \cdot\left(\frac{n-n^{\prime}}{n+1}\right)=-\left(\frac{R-R^{\prime}}{R+1}\right)-0.056
$$

2) Based on the average composition of distillate and yield of a more volatile component, for the sharpness of separation, the following equation for the minimum number of theoretical plates and minimum reflux ratio, respectively, were obtained.

$$
\begin{aligned}
n^{\prime} & =\frac{1}{\log \alpha} \log \left(\frac{\log (1-\eta)}{\log (1-\delta)}\right) \\
R^{\prime} & =\frac{\log (1-\eta)-\alpha \log (1-\delta)}{(\alpha-1) \log (1-\beta)}
\end{aligned}
$$

where,

$$
\delta=\eta\left(\frac{x_{0}}{1-x_{0}}\right)\left(\frac{1-x_{D} \mathrm{av}}{x_{D} \mathrm{av}}\right), \quad \beta=\eta x_{0} / x_{D} \mathrm{av}
$$

3) Based on the average composition of distillate and yield of a more volatile component for the sharpness of separation, the correlation between the number of theoretical plates and reflux ratio was obtained as shown in Fig. 5, where the values of $\left(R-R^{\prime}\right) /(R+1)$ ranged from 0.15 to 0.50 , said correlation being represented by the following equation.

$$
\log \left(0.57 \frac{R^{\prime}}{n^{\prime}}\right) \cdot \alpha^{\left(0.149 n^{\prime}+1.281\right)} \cdot\left(\frac{n-n^{\prime}}{n+1}\right)=-\left(\frac{R-R^{\prime}}{R+1}\right)-0.056
$$

- Faculty of Engineering. Nihon University

** Japan Atomic Energy Research Institute

\section{空気輸送におけるビニール管の帯電量について}

ニューマチックコンベヤにビニール管

を用いた場合の帯電についてはしばしば

䅅験する所であるが，带電量の測定は困

難で信頼性に乏しい。一広験䉓器（ライ デン瓶）を用い䇴の開き角と電压の関俰 を検定によって求めて拈いて $3 / 4^{\prime \prime}$ 管に おけるフラィフッシュの輸送について実 测してみたので,参考までに混合比 $m$ に よる变化状況を付図に示す。むちろん実 驗時の湿度や絶粶程度によって異なるで あろ 5 から，精 度の高いもので はないか，大体 常用状㦔の值て ある。'測定位翼 は4 mの輸送管 の中央部に 38 cmの長さに0.2 $\mathrm{mm}$ 厚さのフル ミ簿をまきつ け，その中央か ら直接簿量位諳
に導線をつないた。图からかかるように 混合比 $m$ が 1 以上になると大体電圧お よび電荷量は飽和してくる。時間的な㚆 化は固体供給を開始後 1 分位で平衡状㿟 に澾し，混合比 $m$ が 2 以上の䬶いとき には時々荷荷が急減してまた元にるどる という固体粒子に上る放奄の如き現象が おこる。固体の供給を停止すると急速に 電荷は漏洩して消失する。

（井伊谷鋼一, 神村尼雄) 